\title{
Clays: Colloidal Properties in Nanodomain
}

Siddhartha S. Mukhopadhyay

Electron Microscopy and Nanoscience Laboratory,

Punjab Agricultural University

Ludhiana - 141004, India

[e-mail <siddhartha_soil@yahoo.co.in>,

<ssmukho@pau.edu>] 


\section{Why clay?}

- The ever-growing application of clays in nanotechnology rests on fundamental principles of colloid chemistry

- They make soils as nature's great electrostatic chemical reactor

- The unit cell dimensions of clay minerals are in nanometer scale in all three axes

( $\mathrm{x}, \mathrm{y}$, and $\mathrm{z}$ ) 


\section{Differences with other colloidal material}

- Anisotropic and often irregular particle shape

- broad particle size distribution

- different types of charges within the unit cells

- heterogeneity of layer charges

- pronounced CEC

- disarticulation and flexibility of layers

- different modes of aggregation 


\section{advantages of clays}

- their ordered arrangements,

- their large adsorption capacity,

- their shielding against sunlight (ultraviolate radiation),

- their ability to concentrate organic chemicals, and

- their ability to serve as polymerization templates. 


\section{Industrial uses of clay}

- Petroleum refinery

- Cement

- Soaps, detergents, shampoos, lipsticks

- Pesticide carrier

- Ceramics, pottery and sculpture

- Fertilizer conditioner

- Environmental clean up operations

- Pharmaceuticals and catalyst 


\section{Nanomaterials}

- either newly-created through nanotechnology, or that exist in nature

- Example:

- clays, zeolites, imogolite, Fe \& Mn oxides

- Potential:

- to manipulate structures or other particles at the nanoscale and to control and catalyze chemical reactions 


\section{nanomaterial}

Applications:

- provide transparency, or increased strength with decreased weight

- Smart fabrics

- Controlled Environment Agriculture 
Some successful ventures of nanotechnology involving clay

\begin{tabular}{|c|c|c|}
\hline Product & Application & Institution* \\
\hline \multirow[t]{2}{*}{ Nanocides } & $\begin{array}{l}\text { pesticides encapsulated in nanoparticles for } \\
\text { controlled release }\end{array}$ & BASF \\
\hline & nanoemulsions for greater efficiency & Syngenta \\
\hline $\begin{array}{l}\text { Bucky ball } \\
\text { fertilizer }\end{array}$ & ammonia from buckyballs & $\begin{array}{l}\text { Kyoto Univ, } \\
\text { Japan }\end{array}$ \\
\hline $\begin{array}{l}\text { Nanoparticle } \\
\text { s }\end{array}$ & $\begin{array}{l}\text { Adhesion-specific nanoparticles for removal of } \\
\text { Campylobacter jejuni from poultry }\end{array}$ & Clemson Univ. \\
\hline $\begin{array}{l}\text { Food } \\
\text { packaging }\end{array}$ & $\begin{array}{l}\text { airtight plastic packaging with silicate } \\
\text { nanoparticles }\end{array}$ & Bayer \\
\hline $\begin{array}{l}\text { Use of agri- } \\
\text { cultural } \\
\text { waste }\end{array}$ & $\begin{array}{l}\text { nanofibres from cotton waste for improved } \\
\text { strength of clothing }\end{array}$ & Cornell univ \\
\hline \multirow{2}{*}{$\begin{array}{l}\text { Nano- } \\
\text { sensors }\end{array}$} & contamination of packaged food & Nestle, Kraft \\
\hline & pathogen detection & Cornell Univ \\
\hline $\begin{array}{l}\text { Precision } \\
\text { agriculture }\end{array}$ & $\begin{array}{l}\text { nanosensors linked to GPS for real-time } \\
\text { monitoring of soil conditions and crop growth }\end{array}$ & USDA \\
\hline $\begin{array}{l}\text { Live stock } \\
\text { and fisheries }\end{array}$ & $\begin{array}{l}\text { nano-veterinary medicine (nanoparticles, buckyballs, } \\
\text { dendrimers, nanocapsules for drug delivery, nanovaccines; smart } \\
\text { herds, cleaning fish ponds (Nanocheck); feed (iron nanoparticles) }\end{array}$ & $\begin{array}{l}\text { Cornell Univ, } \\
\text { Nanovic, }\end{array}$ \\
\hline
\end{tabular}




\section{Possible innovations}

- nano-enhanced products (e.g. nanofertilizers and nanopesticides)

nano-based smart delivery system (use of halloysite)

- Nanoporous materials (e.g. hydrogels and zeolites)

- nanoporous membranes

- Nanosorbents

- Nanocrystals of magnetite (<12 nm)

- Nanosensors

- nanoscale precision farming 
Soil mineral structures 

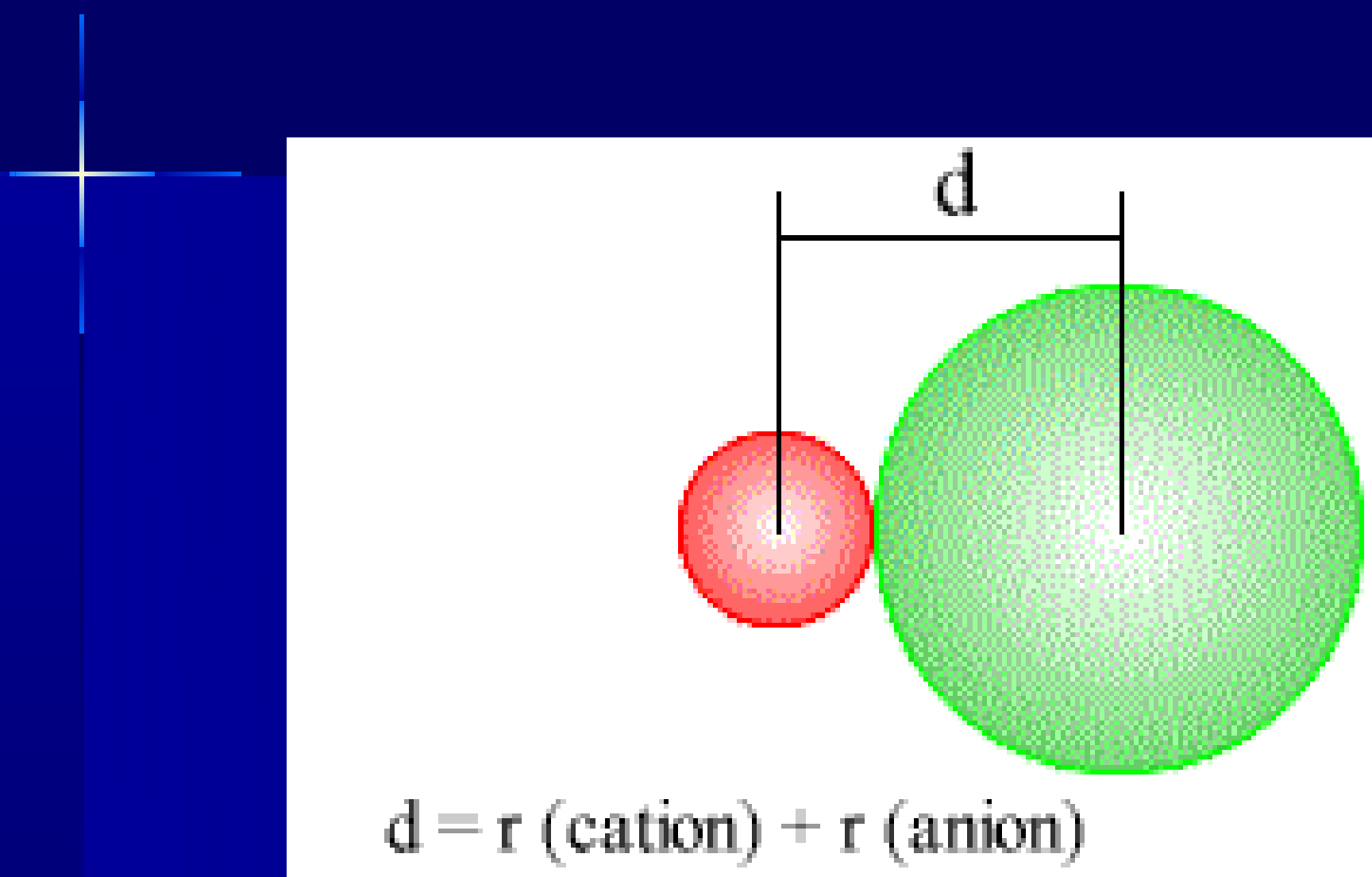


\section{Si tetrahedra and Al octahedra in clay minerals}

\section{Ifernatiedrom}

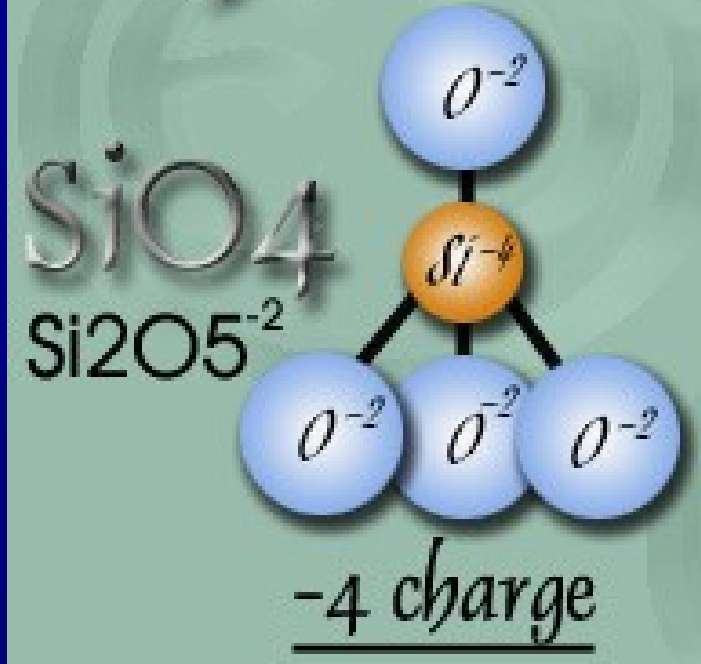

octabedral

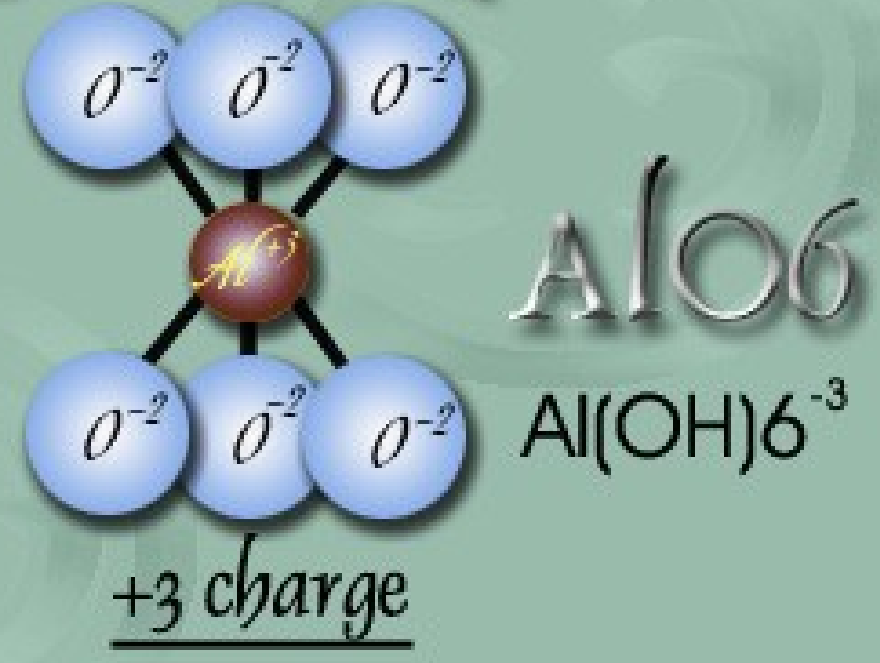

The Mystery of Clays - Eytons' Earth 


\section{Structure of kaolinite (China clay)}
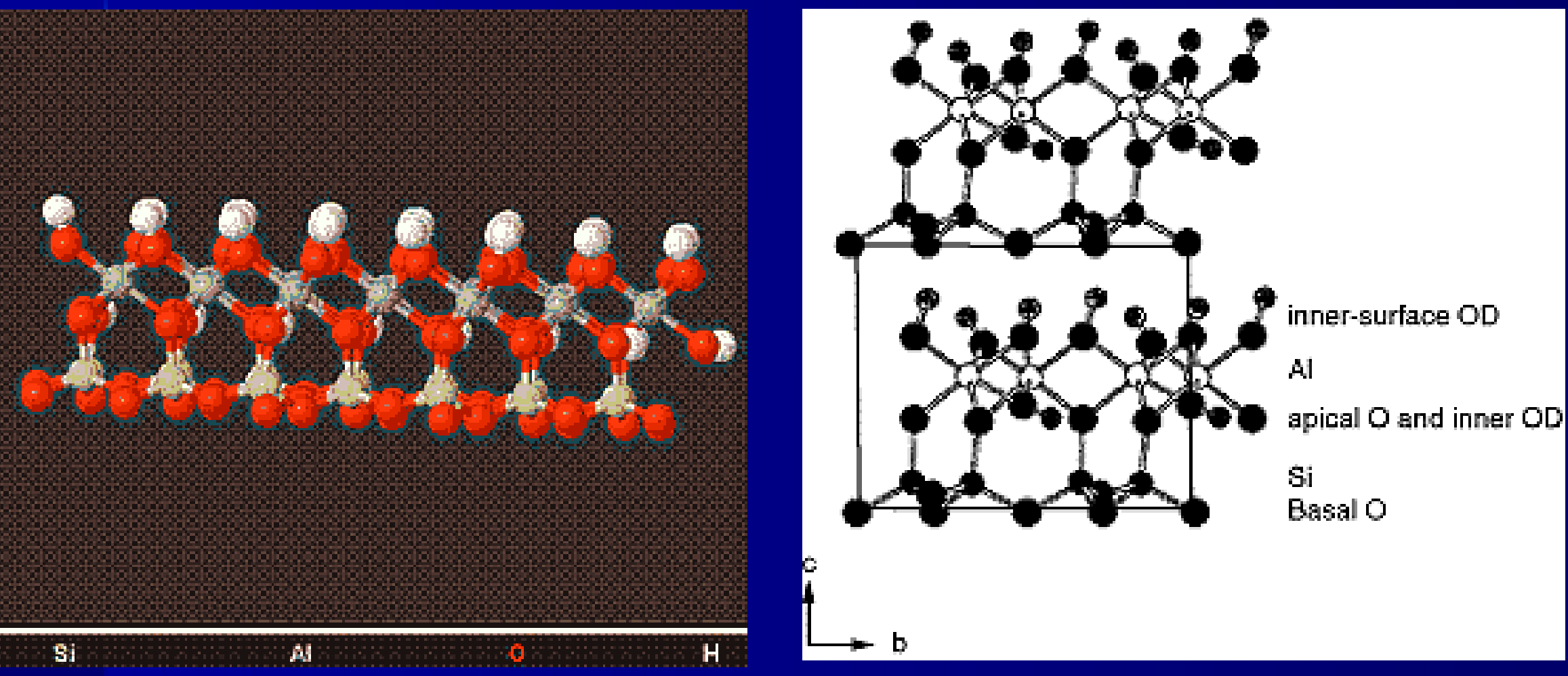


\section{Structure of} MONTMORILLONITE
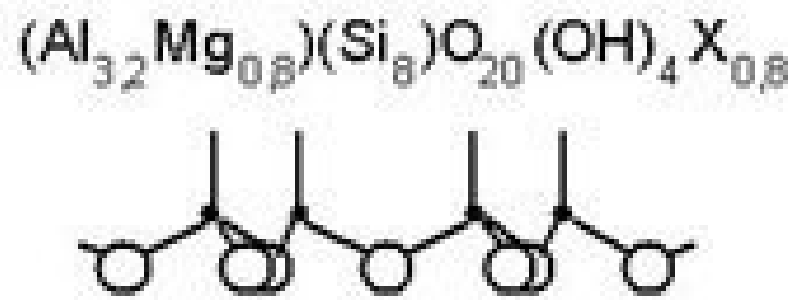

$$
\mathrm{Na}^{+} / \mathrm{Ca}^{++}
$$

TETRAHEDRAL

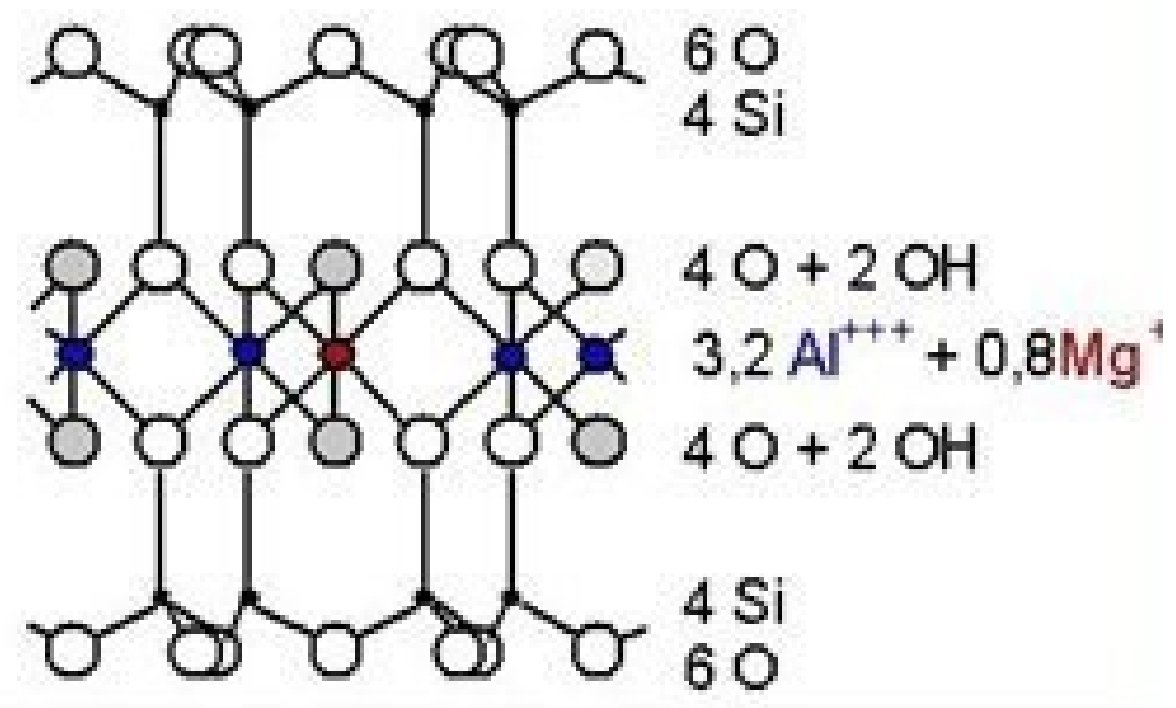

OCTAHEDRAL

TETRAHEDRAL 


\section{Tectosilicates: Zeolite}

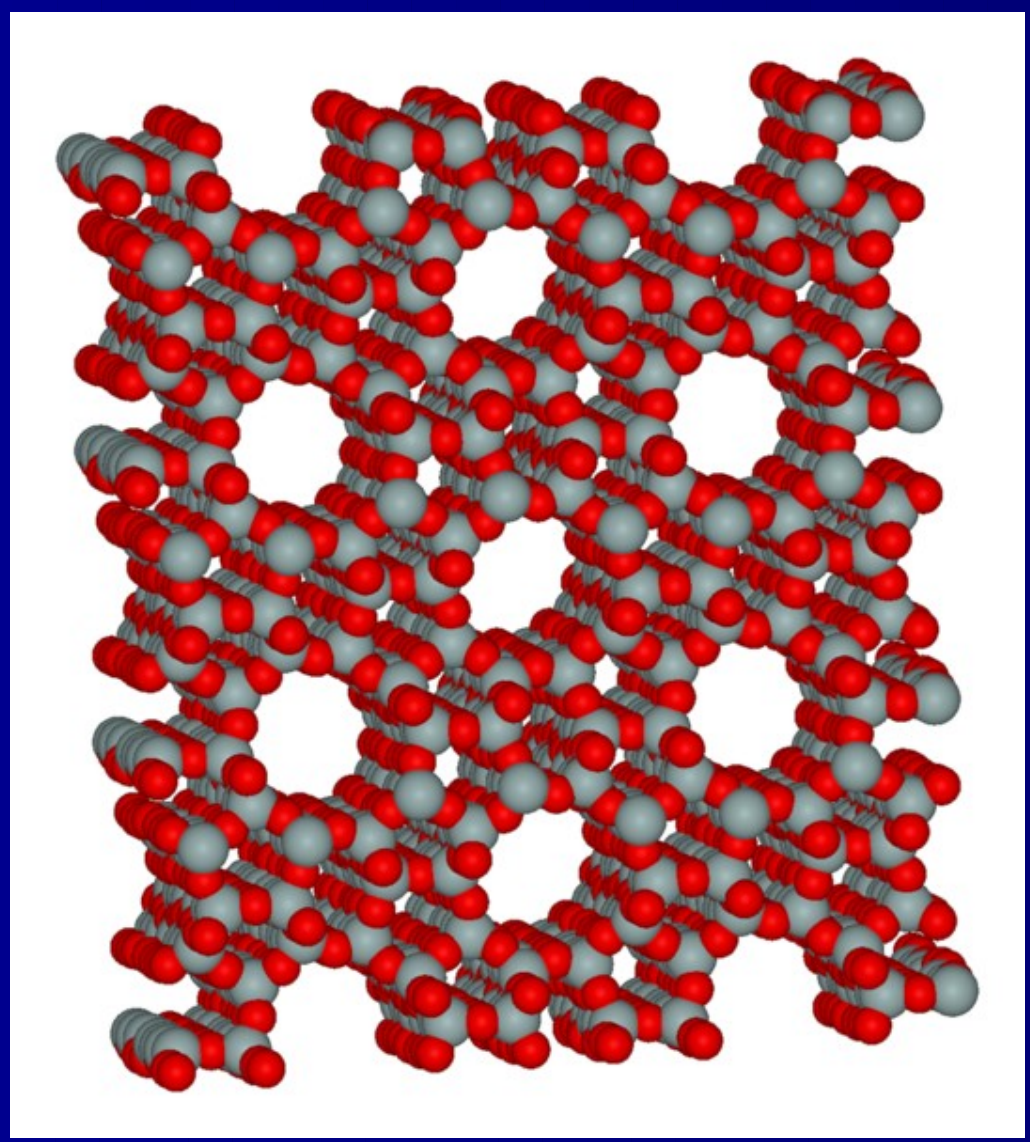




\section{TEM of a zeolite}
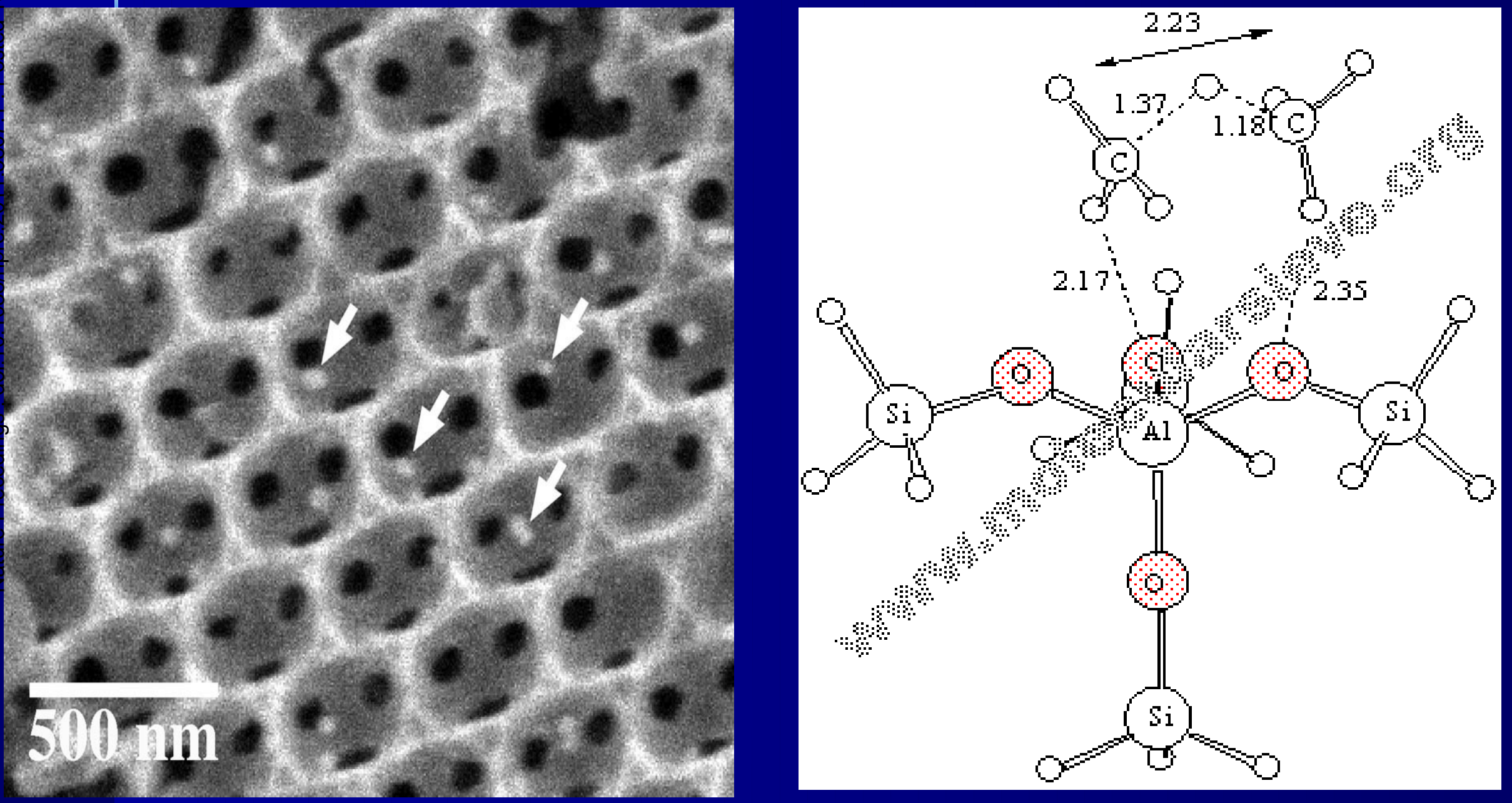


\section{Birth of semicondctivity}

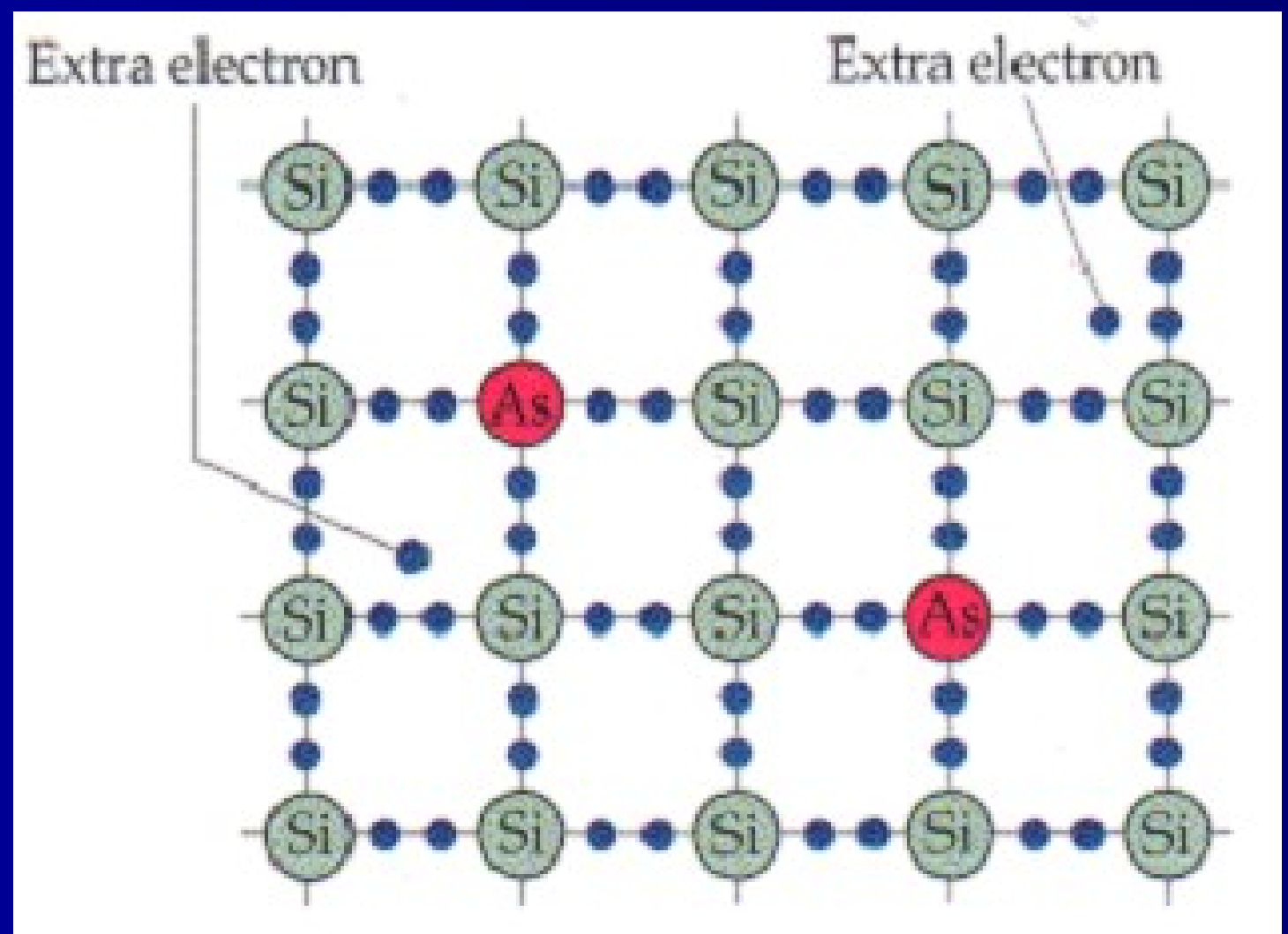




\section{Promises of nanotechnology}

- greatest technological breakthrough in

history, doing for our control of matter what computers did for our control of information.

- Though limits to growth will remain, we will be able to harvest solar power a trillion times greater than all the power now put to human use. 


\section{Defining nanotechnology}

- is a new interdisciplinary venture-field

that converge science, engineering, and agriculture and food systems into one -

Dr. APJ Abdul-Kalam

- understanding and control of matter at dimensions of roughly $1-100 \mathrm{~nm}$, where unique physical properties make novel applications possible (EPA, 2007). 


\section{What will nano materials do to the environment?}

- Our expanding ability to synthesize nanoparticles for use in electronics, biomedical, ceramics, pharmaceutical, cosmetic, energy, environmental, catalytic, material etc. has alarmed concern

\begin{tabular}{|c|c|}
\hline Year & $\begin{array}{c}\text { Amount of } \\
\text { Engineered } \\
\text { material } \\
\text { used }\end{array}$ \\
\hline 2004 & 2000 tons \\
\hline $2011-2020$ & $\begin{array}{c}58000 \text { tons } \\
\text { (expected) }\end{array}$ \\
\hline
\end{tabular}
for these particles role 


\section{Zeophonics}

- Sysstem founded on the concept of interconnected nature of all life-forms and life-support-forms

- Relies on recycling and operation of system-components

- The system provides a framework where impetus and response are almost equal. 
- This is the only means of survival in the extraterrestrial planets, space stations,

fand in the Antarctica 
Nanotechnology in agriculture is

like a game of Quiddich that

Harry Potter and other pupils played

in the School of Magic.

No matter what's the score, if

the seeker catches snitch,

his team wins. 


$$
\text { Thank you }
$$

